\title{
ДОСВІД РОБОТИ ЩОДО ПІДВИЩЕННЯ ЯКОСТІ ПІДГОТОВКИ ІНОЗЕМНИХ СТУДЕНТІВ
}

\author{
Г. В. Дзяк, Т. О. Перцева, Л. Ю. Науменко, Г. В. Горбунова \\ Дерэсавний заклад “Дніпропетровськамедична академія Міністерства охорониздоров'я Украйни”

\section{EXPERIENCE OF THE FOREIGN STUDENTS' TRAINING QUALITY IMPROVMENT}

\author{
H. B. Dzyak, T. O. Pertseva, L. Yu. Naumenko, H. V. Horbunova \\ State Institution "Dnipropetrovsk Medical Academy of Ministry of Public Health of Ukraine"
}

\begin{abstract}
У статті розглянуті досвід роботи та система заходів, спрямовані на підвищення якості підготовки студентів - громадян іноземних країн, які обрали майбутню спеціальність лікаря.
\end{abstract}

The article concerns the experience and the activities system aiming the training quality improvement of the foreign students who pursuit the higher goal - to become a doctor.

Вступ. Інтеграція України в Свропейський простір невід'ємно пов'язана з розширенням міжнародної діяльності вищих навчальних закладів, що в галузі підготовки лікарів привело до збільшення студентів - громадян іноземних країн, які здобувають медичну освіту в нашій країні.

Основна частина. У державному закладі “Дніпропетровська медична академія МОЗ України” склалась певна система організації роботи щодо підвищення якості підготовки іноземних студентів. Серед напрямків роботи: активна профорієнтаційна робота щодо формування здатного до навчання в академії контингенту студентів з числа іноземних громадян; організація оптимального навчального процесу для іноземних громадян на підготовчому відділенні, додипломному та післядипломному етапах; створення і постійне поліпшення умов мешкання і побуту іноземних студентів; організація і контроль за дозвіллям іноземних студентів і слухачів підготовчого відділення; профілактика правопорушень з боку іноземних студентів і громадян України проти них; участь у розширенні міжнародних відносин академії через іноземних студентів тощо.

В академії склалась система співпраці з університетами країн світу. Серед них : Вейфанська медична академія (КНР), Шандунський університет традиційної китайської медицини (КНР), Міжнародний Казахсько-Турецький університет Х. А. Ясаві (Казахстан), Штутгартський університет (Німеччина), університет м. Мюнстер (Німеччина), університет

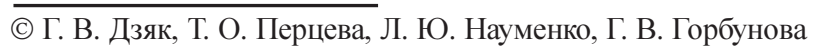

м. Хайдельберг (Німеччина), Інститут ревматології РАMН Росії, Ташкентська медична академія, Придністровський державний університет імені Т. Г. Шевченка, Вітебський державний ордена Дружби народів медичний університет (Білорусь), Таджицький державний медичний університет імені Абу Алі Ібн Сіни.

Державний заклад “Дніпропетровська медична академія МО3 України” щорічно збільшує набір студентів - громадян іноземних країн. У 2013-2014 навчальному році контингент іноземних студентів складає 1558 осіб з 48 країн світу. В їх числі: 1324 студенти за фахами "Лікувальна справа", "Стоматологія", "Фармація", "Medicine”, "Stomatologya"; 148 слухачів підготовчого відділення; 28 магістрів; 51 клінічний ординатор; 7 аспірантів.

Динаміка зарахування іноземних студентів за останні роки позитивна: у 2011 році зараховано 413 іноземних громадян, у 2012 році-474, у 2013 році-609 іноземних громадян. У 2013 році делегацією академії проведені зустрічі з представниками Міністерства охорони здоров'я Індії та посольства України в Індії, організовані семінари-презентації ДМА в школах різних штатів Індії. Як результат маркетингової роботи академії в 2013-2014 році вперше навчаються на I курсі та підготовчому відділенні 100 громадян Індії. На цей час в академії 300 іноземних студентів навчаються англійською мовою.

Збільшення кількості студентів потребувало реформування управління організацією навчального процесу іноземних студентів. В академії створено два міжна- 
родні факультети: 1-й організовує навчання студентів I-III курсів, 2-й забезпечує організацію навчального процесу студентів IV-VI курсів.

В умовах кредитно-модульної системи організації навчального процесу вимоги до іноземних студентів не відрізняються від вимог до вітчизняних студентів. Лекції, практичні заняття, практика проводяться згідно з розкладом. Методичне забезпечення навчального процесу здійснюється російською та англійською мовами. Декілька навчально-методичних посібників для позааудиторної та самостійної роботи іноземних студентів, що створені професорсько-викладацьким складом академії, мають гриф МОН України. Доступність викладання матеріалу, постійний контроль знань, повноцінне методичне забезпечення, врахування національно-психологічних рис особистості іноземного студента - необхідні складові навчального процесу.

Ставлення викладача до іноземних студентів передбачає: вимогливе та поважне ставлення; конкретизацію зауважень; відсутність узагальнень, особливо в негативному, принизливому аспекті; демонстрацію віри викладача у здібності студента з метою підвищення мотивації до навчання; виділення кращих студентів для мотивації їх до подальших успіхів тощо.

Навчання студентів англійською мовою стимулює викладачів удосконалювати не лише володіння іноземною мовою (з носіями мови), але й професійну майстерність. В 2010, 2011 роках змінився контингент англомовних студентів, які прийшли на 1 курс. Вперше за 8 років англомовного навчання в ДМА з'явилися студенти, які не є носіями англійської мови. Володіння англійською мовою деяких студентів, як 3'ясувалося, залишає бажати кращого. Вимоги до цього контингенту іноземних студентів також підвищуються: деякі з іноземних студентів, які показали незадовільне знання англійської мови, переведені на підготовче відділення, а частину студентів відраховано з академії (у 2011 році - 8 студентів, у 2012 році - 7 студентів, у 2013 році - 5 студентів та 1 студент у 2014 році).

3 метою підвищення якості підготовки іноземних англомовних студентів в академії проведені атестація викладачів та їх розподіл на групи з високим рівнем підготовки, достатнім та середнім рівнями володіння англійською мовою, створені курси занять щодо підвищення кваліфікації для викладачів $з$ англійської мови.

При аналізі успішності іноземних студентів виявлені недоліки підготовки з загальних базових шкільних дисциплін, що не дає їм можливості засвоювати нові знання, необхідні в майбутній професійній діяльності. У зв’ язку з цим у 2013 році в академії було прийнято рішення щодо підвищення вимог до абітурієнтів громадян іноземних країн.

Всі етапи вступу (подання документів, допуски, проведення іспитів та співбесіди, рішення приймальної комісії, формування наказів) проводились через Сдину базу МОН України, яка пов’язана з базою ДМС України.

Іноземці подають документ про освіту та одержані 3 навчальних дисциплін оцінки (бали) з середнім балом не нижче 150 балів за 200-бальною шкалою (не нижче 50 \% відповідної шкали країни) за умови отримання не нижче 124 балів з непрофільних конкурсних предметів та не нижче 140 балів 3 профільних конкурсних предметів $з$ такими ж критеріями на вступних іспитах. При прийомі 2013 року було введено вступні випробування:

- за спеціальністю "Лікувальна справа" та "Стоматологія” з предметів: біологія (профільний, співбесіда) та з російської або англійської мови (письмово);

- за спеціальністю “Фармація” з предметів: хімія (профільний, співбесіда) та з російської або англійської мови (письмово).

На наш погляд, підвищення вимог до рівня знань абітурієнтів з предметів шкільної програми дає надію щодо підвищення засвоєння іноземними студентами вузівських програм під час навчання в академії. Слід відмітити, що відмова на етапі видачі запрошень при подачі документів складала 4,5 \%. При проведенні іспиту з російської мови в Республіці Узбекистан (17 серпня 2013 року) із 65 абітурієнтів відмова - у 35 осіб (53,8 \%); відмова на іспитах та співбесідах - 73 абітурієнти (16,6 \%). Всього 145 абітурієнтів отримали відмову від прийому на навчання.

Такий підхід дозволив виявити недоліки у підготовці абітурієнтів, завдяки чому було надані пропозиції деяким абітурієнтам щодо навчання на підготовчому відділенні академіі.

Є певні проблеми з якістю успішності іноземних студентів на ліцензійних іспитах. В академії ведеться їх підготовка до ліцензійних іспитів у формі тренінгів - проведення ректорських контролів за технологією ДО “Центр тестування МОЗ України” в аудиторіях, які обладнані аудіо- та відеоспостереженням: бланк відповіді, розсаджування за алфавітом, видача буклетів з 200 тестовими завданнями, час на їх вирішення. Тестові завдання використовуються як “якірні” останніх років, так і з первинної бази ДО “Центр тестування MO3 України”, що рекомендовані для підготовки до ліцензійних іспитів. 
Особлива увага приділяється вирішенню умов навчання, проживання, дозвілля, що пов'язано з адаптацією студентів в нашій країні. 3 метою прискорення адаптації іноземних студентів до вузівських умов, формування з багатомовної інтернаціональної групи повноцінного студентського колективу в академії відновлено інститут кураторів, до складу якого увійшли найбільш досвідчені викладачі, які працюють на перших курсах.

3 метою адаптації іноземних студентів до нових умов в академії в перші тижні їм допомогають студенти-куратори, які володіють англійською, або китайською, або арабською мовами. Гуртожиток у центрі міста повністю віддано іноземним студентам (у наявності 416 місць), частина іноземних студентів проживає в інших гуртожитках академії.

Особлива увага приділяється формуванню громадських об'єднань іноземних студентів. Рада іноземних студентів об'єднує 9 первинних асоціацій: арабських студентів - “Аль Мустакбаль”, узбецьких - "Комолот", китайських - "Студентська земля”, марокканських студентів - “Зелена зірка”, туркменських студентів - “Галкинши”, об'єднання студентів Іраку, Сирії, Йорданії та Палестини. Вони проводять роботу щодо підтримки студентів у вирішенні проблем адаптації, беруть участь у благодійній діяльності щодо дитячих садків тощо.

Медична допомога іноземним студентам надається на базі обласної клінічної лікарні на підставі Закону України "Про страхування" (стаття 9), "Про правовий статус іноземців та осіб без громадянства" (стаття 10).

Причинами відрахування іноземних студентів за останні 4 роки є: за власним бажанням, за академічну заборгованість, за порушення навчальної дисципліни, переведення до інших ВНЗ, за порушення умов контракту (несплата за навчання), неповернення 3 Батьківщини, не склав “КРОК-2", за порушення паспортного режиму. Кількість відрахованих щорічно зменшується $(68$ - у 2010 р., 28 - у 2011 р., 50 - у 2012 p., 15 - y 2013 p.).

Особлива увага приділяється виховній роботі з іноземними студентами:

\section{Література}

1. Кредитно-модульна система організації навчального процесу у вищих медичних (фармацевтичному) навчальних закладах України на новому етапі : матеріали Х ювілей-
- проводяться “круглі столи” з питань "Молодь за расову та етнічну толерантність" за участю студентів з Анголи, Нігерії та Судану. Ці зустрічі транслювались на трьох каналах Дніпропетровського телебачення;

- іноземні студенти беруть участь в українських національних святах, вивчають традиції українського народу, запрошують українських студентів на свої національні свята (КНР, Нігерія, Ангола та ін.);

- проводяться засідання “Клубу інтернаціональної дружби" тощо.

3 метою безпеки іноземних студентів охорона у гуртожитках академії виконується фірмою "Муніципальна гвардія" з 17-00 щоденно.

Серед заходів щодо підвищення якості підготовки іноземних студентів слід виділити такі: підвищення вимог до рівня знань абітурієнтів з біології, хімії, російської та англійської мов; збільшення обсягу методичних видань для іноземних студентів; впровадження в навчальний процес сучасних наукових досягнень на засадах доказової медицини; подальша активізація роботи щодо організації англомовного навчання іноземних студентів та відповідної підготовки професорсько-викладацького складу; на кафедрах посилення контролю щодо засвоєння іноземними студентами теоретичних знань як основи до якісної підготовки до ліцензійних іспитів "КРОК-1" та "КРОК-2"; проведення індивідуальної роботи зі студентами 3 “групи ризику”; активне залучення іноземних студентів до СНТ та участі в олімпіадах, конференціях; забезпечення подальшого оперативного вирішення побутових і соціальних проблем іноземних студентів.

Висновки. Підвищення якості підготовки іноземних студентів до професійної діяльності, формування їх практичних вмінь та навичок потребує подальшого системного вирішення проблем як ретельного відбору абітурієнтів, так і подальшого удосконалення організації навчального процесу, підвищення педагогічної майстерності викладачів, підвищення вимог до рівня знань студентів, підвищення відповідальності студентів за якість освіти, яку вони отримують.

ної Всеукр. навч.-наук. конф. 3 міжнар. участю : у 2 ч., Тернопіль, 18-19 квіт. 2013 р. - Тернопіль : ТДМУ, 2013.Ч. $1 .-634$ c.; Ч. 2. -700 c. 